\title{
Studying the effect of ore texture on the Bond Work Index at the Mahd Ad Dahab Gold Mine: a case study
}

The Mining-Geology-Petroleum Engineering Bulletin UDC: 622.7

DOI: 10.17794/rgn.2020.1.9

Original scientific paper

\author{
Gamal S. Abdelhaffez ${ }^{1,2}$ \\ ${ }^{1}$ Department of Mining Engineering, Faculty of Engineering, King Abdulaziz University, Jeddah, KSA (Current address) \\ ${ }^{2}$ Mining \& Metallurgical Eng. dept., Faculty of Engineering, University of Assiut, Egypt, 71516 (Permanent address), \\ ORCID (https://orcid.org/0000-0002-3400-0784)
}

\begin{abstract}
The grinding process in industrial ball mills is the basic unit and most energy-consuming component. Therefore, great economic gains will be achieved if a slight improvement occurs in the efficiency of grinding. The variation of gold ore petrography affects its mechanical properties which in turn, affects the grinding process. In this investigation, different gold-bearing ore types from the Mahd Ad Dahab gold mine were tested. As a part of the current study, some of the mechanical and physical properties including strength properties, geological characterization and Bond work index were determined. This investigation showed that the Bond work index increases with an increase in rock strength properties. The maximum difference in the Bond work index for the five tested gold ores was $11 \%$ (e.g. $\frac{20.4 \mathrm{kWh} / \mathrm{ton}-18.2 \mathrm{kWh} / \text { ton }}{20.4 \mathrm{kWh} / \text { ton }} \times$ $\times 100 \cong 11 \%$ ). Whereas, an average interval between the two-sequence types of the tested ore was approximately $2.5 \%$. (e.g. $\frac{20.4 \mathrm{kWh} / \text { ton }-19.9 \mathrm{kWh} / \text { ton }}{20.4 \mathrm{kWh} / \text { ton }} \times 100 \cong 2.5 \%$ ).
\end{abstract}

Keywords:

Grinding process; Bond Work index; gold ore petrography; Mahd Ad Dahab mine

\section{Introduction}

Grinding is the last step in comminution. Such a step is necessary to attain the required size, either in a dry or wet medium, to liberate the locked valuable minerals from the host rock, and to expose more surface area for contact. The correlation between the failure criteria of rocks and their mechanical properties has been presented in various literature. Researchers found that brittle rocks fail as a result of a micro-cracks' widening under uniaxial compression tests, whereas this failure attributes to the coalition of these micro cracks under confining pressures. Rock strength properties increase as lateral pressure increases and the switching from elastic to plastic deformation occurs (Paterson and Wong, 2005; Kwaśniewski, 2013; Abdelhaffez, 2012). Several researchers have shown that the particle size, surface area and ore texture are important parameters in controlling rock failure. Thus, they are used to understand the behavior of different rocks that have same matrix (Howarth and Rowlands, $1986 \& 1987$; Ersoy and Waller, 1995; Azzoni, 1996; Ozturk and Nasuf, 2002). To measure a

Corresponding author: Gamal Abdelhaffez gamalhaffez@gmail.com material's resistance in a crushing and grinding operation, the grindability test is widely employed to predict the energy requirements. Specific crushing energy is used to select plant-scale comminution equipment, which is primarily based on rock strength properties (Badr and Abdelhaffez, 2014). A study has been conducted by Korman et al., (2015) and it revealed that energy consumption during crushing mainly depends on the individual mechanical properties of rocks. More specifically, rock compressive strength has the utmost impact. Moreover, an increase in the compressive strength increases the proportion of larger particle size (Tomislav et al., 2015). Another study was conducted by Barudžija et al., (2015) to select the appropriate aggregate (e.g. aggregate is produced from crushing) in an asphalt mixture for road reconstruction. The aggregate was tested with respect to resistance to crushing and abrasion. Micro-petrographic analysis and physico-mechanical properties of the tested rocks showed that the most suitable aggregate for road reconstruction is the one with the least amount of water absorption and the highest uniaxial compressive strength (Barudžija et al., 2015).

To find a lab-scale concentration, three chromite ore samples from different sites were examined. This examination depends on the physical and mineralogical 
properties (Yuce, 2017). In this study, mineralogical rock properties have been investigated, more specifically structure, degree of separation, grinding energy (i.e. in terms of the Bond work index), and particle size distribution. The size, shape, and particle distribution of a mineral could be precisely presented using petrological analysis. Such an analysis gives an understanding of the rock texture's formation (Leiss et al., 2000). The comminution rate is eventually impacted by mineral content (Kekec, 2006). Park and Min (2015) investigated the behaviour of composite rock samples subjected to uniaxial loading. They found that fabric, texture and weathering clearly affect rock mechanical properties. Numerous authors have discussed the relationship between consumed grinding energy and rock physical and mechanical properties. Charles' formula has been adopted to determine energy consumption during the grinding operations. Ceramic raw materials (i.e. quartz, kaolin, feldspar) were used in a ball mill. It is found that there is no change in the particle size distribution of minerals after being ground separately or within a mixture (Ipek et. al., 2005). The energy input and size distribution were devolved, in regard to the effect of the input size distribution and types of materials, and they found good relationships and a formula which can be used with good, accurate evolution of the energy for fragments (Petrakis et al., 2017). Comparison between Bolivian Kori Kollo and Egyptian Sukari Gold mines unveiled that the hardness of the ore of the latter is much higher. Researchers concluded that the work index, with a magnitude of $19.1 \mathrm{kw} / \mathrm{t}$, has been set up for about $85 \%$ of sulphide ores. Thus, this value is used to refer to oxide ores.

Analysis of the gyratory product shows that $80 \%$ of $113 \mathrm{~mm}$ was passed and $150 \mu \mathrm{m}$ were extracted by leaching and flotation. Consequently, a grinding circuit was employed without an additional milling capacity. Thus, it restricted throughput to 4Mtpa of mixed and sulphide ore (Rhodes and Penna, 2009). A pebble crusher was needed to separate the competent scats resulting from the SAG mill. Therefore, the annual throughput would increase to 4.6 million tons after the first stage (i.e. oxide ores are brittle). To reach this goal, the ball load of the SAG mill must be set at $15 \%$ and the size of the pebble has to increase to $80 \mathrm{~mm}$ (Rhodes and Penna, 2009). Thus, it is important to reduce operating costs and energy consumption. High-Pressure Grinding Rolls (HPGR), have been adopted as an alternative for better energyefficiency. HPGR takes into account the controlling parameters with respect to the overall consumed energy. HPGR generates a multiple input/output control scheme. Consequently, HPGRs are useful to tackle controlling variables and to represent the exact required velocity and pressure (Eduardo et al., 2019).

Some ores, such as phosphate, magnesite, feldspar, titanium and limestone had been ground by using Vertical roller mills. The comminution system for this mill includes crushing and grinding, which is classified as a drying process and has a good advantage over other conventional systems because it saves $15 \%$ of energy. Whereas, chalcopyrite ores, of a plant having a rod and ball mill under certain conditions, would save $18 \%$ in specific energy consumption (Deniz et al., 2015). Around $26 \%$ of the consumed power in grinding, such as the cement industry, depends on material composition. They were focused on how to reduce energy during the grinding operation. They applied a formula to investigate the performance of the ball mill under air temperature and moisture conditions of the input materials (Adem and Mehmet, 2012).

Composite samples, with varying textures and mineral constitutes, have been used to investigate the influence of heterogeneity on the failure mechanism. The samples were subjected to uniaxial loading. The results reveal that the presence of weak materials (i.e. siltstone) affects the failure mechanism. This study helps the designers to make a decision for choosing the optimum conditions for grinding operations (Liang et al., 2007; Lin et al., 2013). The influence of geomechanical properties and geological settings on the Bond work index has been examined in this investigation. The study is based on a case study of the Mahd Ad Dahab gold mine, Saudi Arabia and implemented various types of goldbearing ores. This study aims to examine the effect of some mechanical properties of well ore texture on the amount of energy consumed during grinding in terms of the Bond work index.

\section{Experimental work}

Five rock samples were collected at different levels as listed in Table 1. The rock samples were prepared according to ASTM standards. Uniaxial compressive strengths, moduli of elasticity, and geological characterization have been determined to evaluate rock grindability using the Bond Work index. The following section presents and discusses the experimental work which has been conducted.

Table 1. Collected rock samples at different levels from the Mahd Ad Dahab mine

\begin{tabular}{|l|c|c|}
\hline $\begin{array}{l}\text { Gold-bearing } \\
\text { ore rocks }\end{array}$ & Mine level & $\begin{array}{c}\text { Elevation from sea level, } \\
\text { m }\end{array}$ \\
\hline Sample 1 & L860 & 861.4 \\
\hline Sample 2 & L880 & 888.7 \\
\hline Sample 3 & L900 & 901.2 \\
\hline Sample 4 & L920 & 922.3 \\
\hline Sample 5 & L940 & 940.8 \\
\hline
\end{tabular}

\subsection{Rock strength properties}

Compressive strength (i.e. UCS) and Moduli of elasticity (i.e. E) have been determined using a testing machine (see Figure 1). For the UCS test, cylindrical rock 


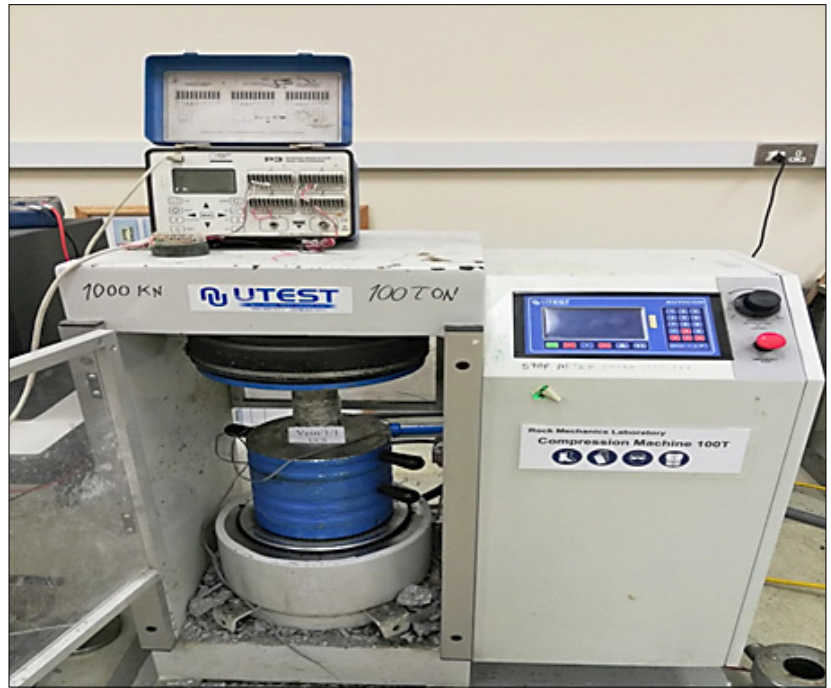

Figure 1. Uniaxial compressive testing machine

specimens of $6.3 \mathrm{~cm}$ diameter and $13 \mathrm{~cm}$ length were cored. A grinding lapping, or polishing machine has been used to make the specimen's ends flat, smooth and free of abrupt irregularities. Three specimens from each level have been uniaxially tested after drying at $105^{\circ} \mathrm{C}$ for $24 \mathrm{~h}$ to conform to American Society for Testing and Materials (e.g. ASTM) standards (Ocak, 2008; Liang et al., 2007).

\subsection{Geological Characteristics of Mahd Ad Dahab Gold Mine}

The geology at the Mahd Ad Dahab deposit (see Figure 2) consists of a basal intermediate to the mafic unit (Lahuf Fm.) that is unconformably overlain by a se- quence of felsic volcanic, volcanoclastic, and epiclastic units (Tuwal Fm). This layered sequence of rocks was intruded by rhyolite porphyry. The succession is comprised of the following units: andesite, lower agglomerate, lower tuff, upper agglomerate, and upper tuff. The rocks of Late Proterozoic (i.e. bimodal basalt-rhyolite volcanic-volcanoclastic) host the gold deposit of the Mahd Ad Dahab mine. These rocks overlay on Dhukhur batholith (i.e. metamorphosed tonalite) (Afifi, 1989; Kemp et al., 1982; Hakim, 1978; Osama and Faisal, 2013). Two formations exist in the mine; the Tuwal Formation unconformably covers the Lahuf Formation. The latter is comprised of subaqueous felsic pyroclastic rocks covered by a sequence of subaerial mafic to intermediate flows, and coarse-grained pyroclastic rocks. The Tuwal Formation includes a lower member of subaqueous felsic pyroclastic rocks, with minor goldstone and chert, and an upper member of subaerial ignimbrites.

\subsection{Grindability measurement of the gold-bearing ore samples}

Grindability data was employed to assess the comminution performance based on various techniques. Over the past years, several criteria have been proposed to introduce grindability. Only two criteria have been accepted, namely Bond grindability and the hardgrove index (i.e. HGI). The latter, HGI, is associated with vertical spindle mills. The Bond index was widely introduced with tumbling mills (Deniz and Onur, 2002; Ahmadi and Shahsavari; 2009; Atilla, 2004; Csőke et al., 2013; Mucsi et al., 2019). In this study, we evaluate grinding energy consumption by applying the standard Bond grindability.

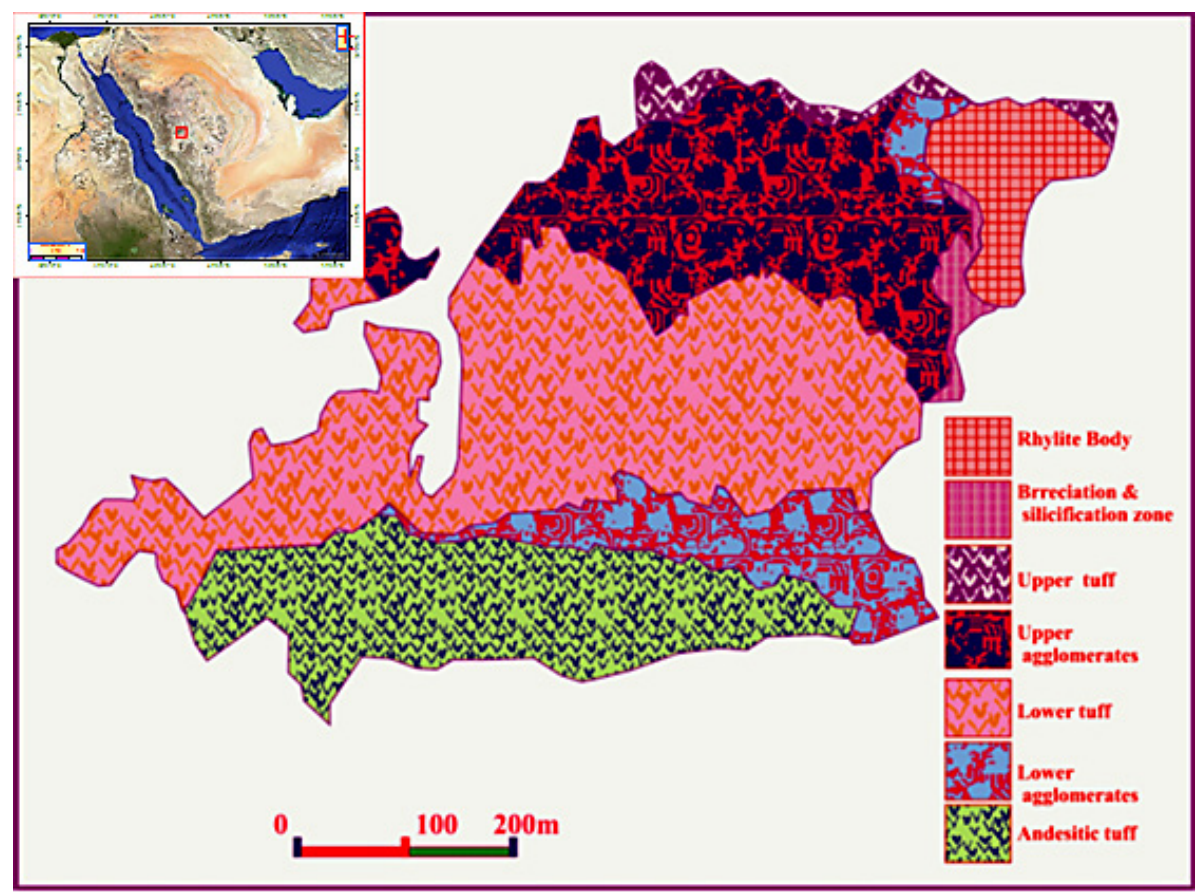

Figure 2. Different lithologies of the selected mine case study area (After Hakim, 1978) 


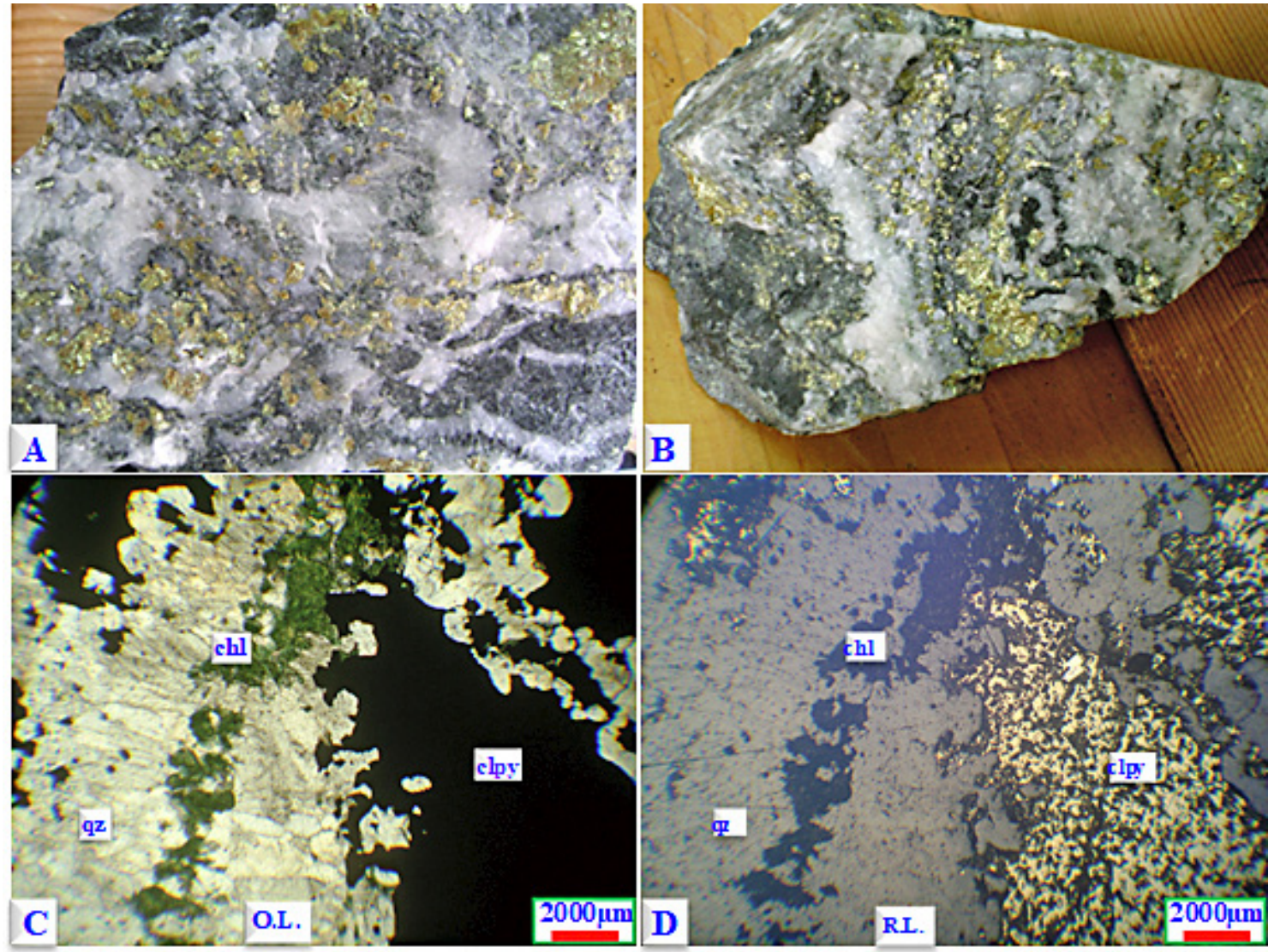

Figure 3. Sample \#1: Chalcopyrite-bearing quartz stock works

Keynotes for Figure 3 - A, B = Polished slabs of the hand samples of the tuffaceous mudstone which are composed of laminated dark tuffaceous pyrite and chalcopyrite rich laminae alternated with light white silicified pyrite and chalcopyrite poor laminae; C, D = Chalcopyrite (Black in C and brass yellow in D) was formed instead of the green chloritic patches. Some chalcopyrite patches are also observed instead of white quartz.

\subsection{Standard Bond tests}

This test was adopted to estimate the amount of energy consumed during the comminution process. Such a test indicates the amount of energy needed (in kilowatts) to grind a ton of rock to a definite size (i.e. $80 \%$ passed $100 \mu \mathrm{m})$. Alternatively, the resistance of rock to being ground is defined by the Bond work index. Thus, it was expected that the Bond work index would not change if the comminution properties of rocks remained unchanged. However, particle size plays an important role in the variation of this index and hence affects the amount of energy consumed. This study was conducted, at the mineral processing laboratory, Mining Engineering department, King Abdulaziz University, Saudi Arabia, using a standard ball mill (i.e. mill dimensions are $305 \mathrm{~mm} \times 305 \mathrm{~mm}$ ) as depicted in Figure 8. The grinding medium (i.e. steel balls) weighed $20.5 \mathrm{~kg}$. The experiment was run in a dry medium, closed-cycle, and a screening process until steady-state was reached (Abdelhaffez, 2012; Ahmadi, 2009). The rock was charged with the grinding medium (i.e. balls) into the mill. The occupied volume weighed $700 \mathrm{~cm}^{3}$ and the mill ran at a speed of $100 \mathrm{rpm}$. The ground rock was sieved and the undersize was weighed. Afterwards, fresh feed was added to the oversize to maintain the original charge at the same weight. The mill speed was determined based on the produced undersize equal to $1 / 3.5$ of the total charge. The grinding cycle lasted until equilibrium state was reached (i.e. it is achieved when the net grams of the sieve undersize produced per mill revolution reaches equilibrium). The circulating load and the undersize product were then analysed and screened. The mean of the final three net grams per revolution defines the grindability of the ball mill. The 100-meshes were used as a test mesh. The Bond work index, $\mathrm{W}_{\mathrm{i}}$ was calculated from Equation 1.

$$
W_{i}=\frac{44.5}{\left(P_{i}\right)^{0.23} \times(G b p)^{0.82} \times\left[\frac{10}{\left(\left(P_{80}\right)^{0.5}-\frac{10}{\left(F_{80}\right)^{0.5}}\right)}\right]}
$$

Where:

$\mathrm{F}_{80}$ : represents $80 \%$ of fresh feed that passes through the ball mill, $\mu \mathrm{m}$. 


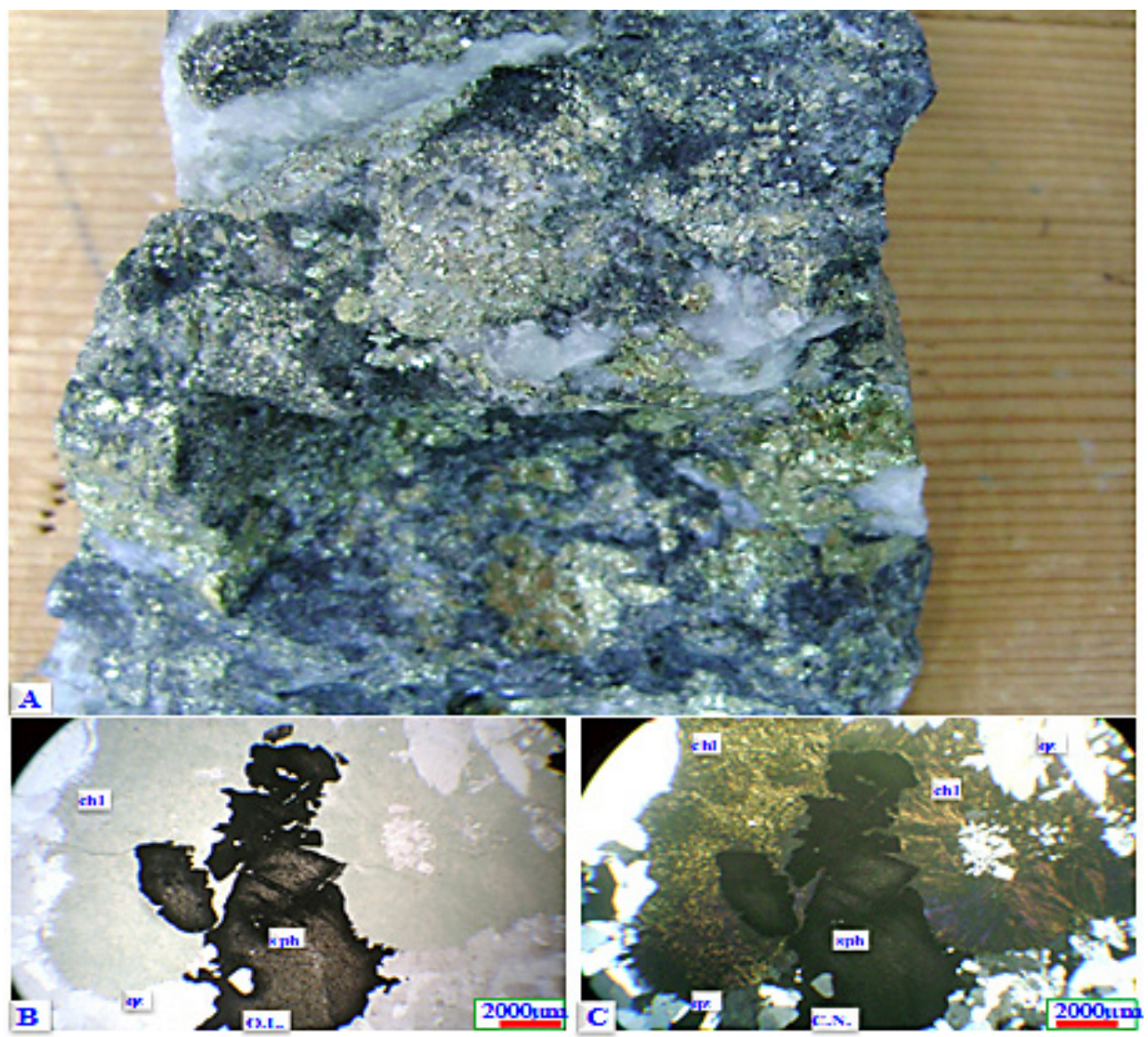

Figure 4. Sample \#2: Chalcopyrite and sphalerite-bearing chloritized and devitrified tuffaceous mudstone

Keynotes for Figure 4 - A = Strong gradation from black tuffaceous mudstone into coarsegrained greenish mineralized white tuffaceous mudstone. The black mudstone is slightly devitrified and contains white coloured quartz patches and domains with less frequent pyrite and minor chalcopyrite patches and domains; B, C = Small sphalerite (sph) patches and domains are observed growing instead of the greened chloritized tuffaceous mudstone (chl).

$\mathrm{P}_{80}$ : defines $80 \%$ of undersize that is produced in the last cycle, $\mu \mathrm{m}$.

$\mathrm{P}_{\mathrm{i}}$ : is the opening size of the sieve, $\mu \mathrm{m}$.

\section{Results and Discussions}

In the following section, the results of the petrographical examination, strength properties and Bond work indices of the five tested gold ore samples are presented and discussed.

\subsection{Texture aspect}

In the Mahd Ad Dahab gold mine, the subsurface field works in the different mine levels revealed the presence of different textures. Five main ore types are texturally described and their core samples are mechanically tested. The host rock of the gold-bearing sulphide minerals is composed of basic to intermediate volcanoclastic. (e.g., tuffaceous mudstones and agglomerates). The orebearing minerals include pyrite ( $a b b r$. py), chalcopyrite (abbr. clpy), sphalerite (abbr. sph) and galena (abbr. gln).
These minerals are intimately associated with gangue minerals which include quartz, devitrified and undevitrified tuffaceous mudstone, chlorite and clay minerals.

\subsubsection{Petrographic Examination of Sample \#1}

This ore type is composed of tuffaceous mudstone which becomes lighter in colour and coarser in grain size and is composed of laminated dark tuffaceous pyrite and chalcopyrite rich laminae alternated with light white silicified pyrite and chalcopyrite poor laminae (see Figure $\mathbf{3 A}, \mathbf{B})$. The light laminae were formed as a result of the progressive devitrification of the tuffaceous material and the replacement of the chalcopyrite (see Figure 3C, D). Chalcopyrite formed instead of the devitrified tuffs and the associated green clays. So, sample \#1 is called Chalcopyrite-bearing quartz stock works.

\subsubsection{Petrographic Examination of Sample \#2}

This ore type shows a very strong gradation from black tuffaceous mudstone into coarse-grained greenish white tuffaceous mudstone. The black mudstone is 


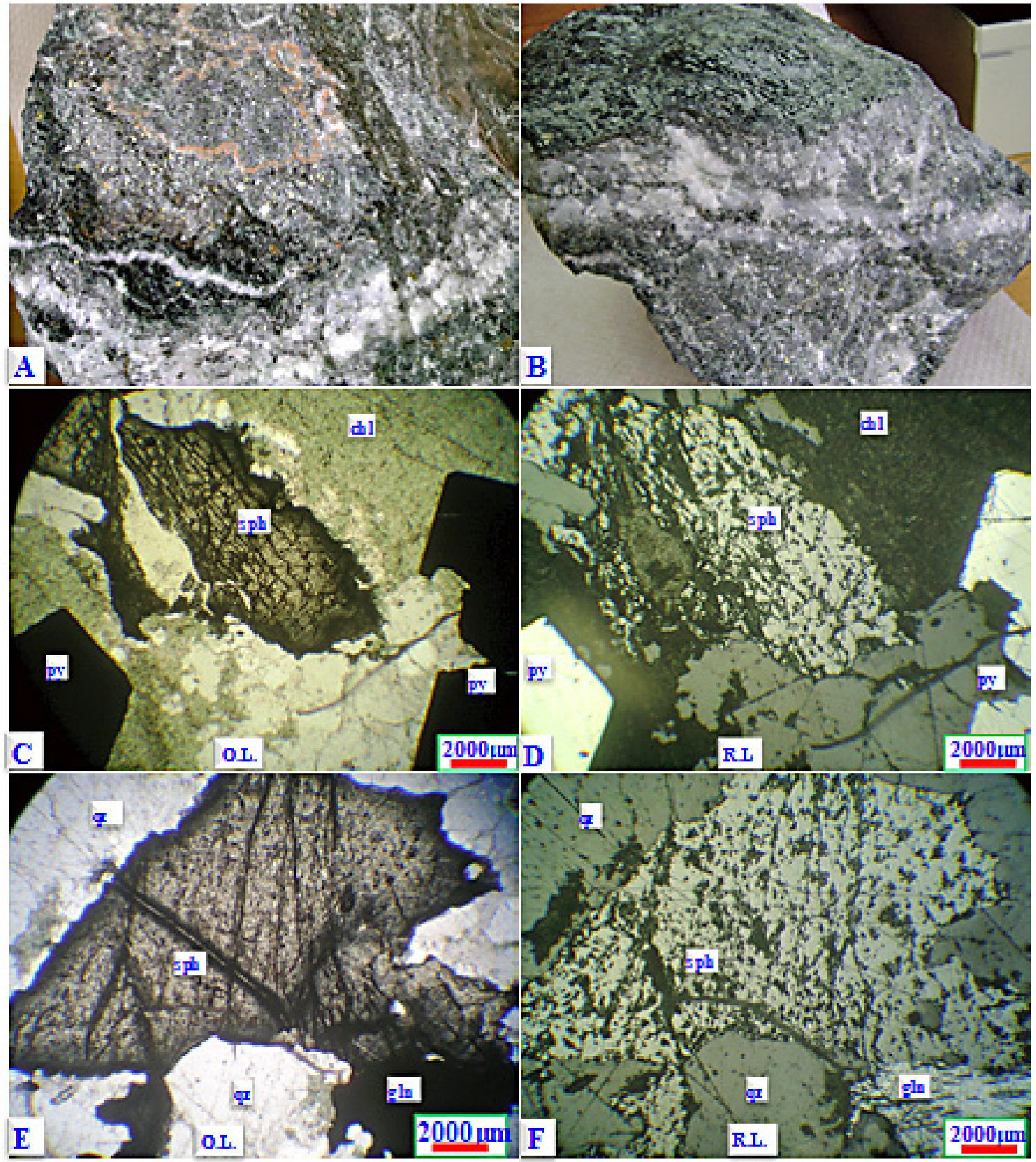

Figure 5. Sample \#3: Sphalerite and Galena-bearing devitrified tuffs

Keynotes for Figure 5. A = Sphalerite bands are present in the lower part which are followed upward by galena and finally by white highly devitrified and silicified bands; $\mathrm{B}=$ The presence of thin bedding characters from black sphalerite and galena-bearing unchloritized and undevitrified bands parallel to white to greenishwhite completely devitrified bands; C, D, E, F = Large sphalerite patches (sph) are also seen growing instead of the greened tuffaceous mudstone (chl). Small galena patches (gl) are also observed in the lowermost right corner of the photos E, F.

slightly devitrified and contains white coloured quartz patches and domains with less frequent pyrite and minor chalcopyrite patches and domains (see Figure 4A). The microscopic description of this black mudstone revealed its composition from greened chloritized tuff which contains small patches of microcrystalline quartz (see Figure 4B, C). Small pyrite and chalcopyrite patches and domains are observed growing instead of the greened chloritized tuffaceous mudstone (see Figure 4B, C).
Therefore, sample \#2 is called Chalcopyrite and sphalerite-bearing chloritized and devitrified tuffaceous mudstone.

\subsubsection{Petrographic Examination of Sample \#3}

The megascopic description of this ore type revealed its composition from thinly laminated black tuffaceous mudstone, which contains a light coloured, devitrified 

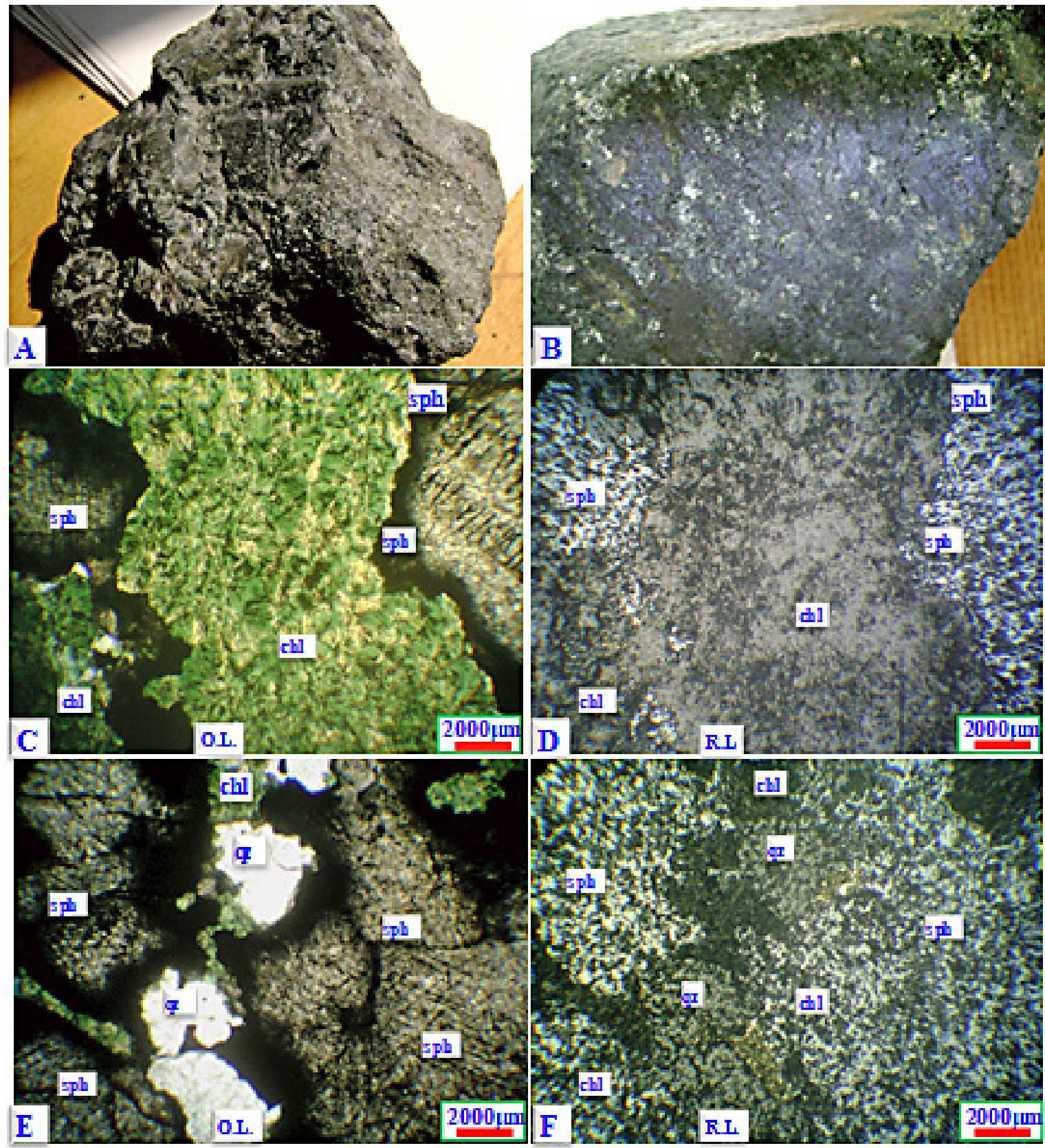

Figure 6. Sample \#4: Sphalerite and chalcopyrite-bearing devitrified friable black tuffaceous mudstone Keynotes for Figure 6 - A = unmineralized black tuffaceous mudstone; B= Slightly oriented disseminated pyrite crystals (light) and patches are observed within this black mudstone; C, D = The growing of sphalerite (sph) instead of the greened mudstone (chl) begins by the formation of small black patches which become larger and well developed; $\mathrm{E}, \mathrm{F}$ = The formed sphalerite patches (sph) were later on replaced by chalcopyrite.

(quartz) and slightly chloritized (green) laminae and stringers (see Figure 5A, B). The microscopic description of these samples revealed the presence of large sphalerite patches and domains as well as coarse euhedral pyrite cubes (see Figure 5C, D). The pyrite cubes are intimately associated with the chloritic patches and domains. Some large sphalerite patches are interlocked with galena of characteristic high reflectivity and triangular pits (see Figure 5E, F). Therefore, sample \#3 is called Sphalerite and Galena-bearing devitrified tuffs.

\subsubsection{Petrographic Examination of Sample \#4}

The samples of the lowermost part of this mine level are composed of unmineralized black tuffaceous mudstone (see Figure 6A) which indicates deposition within highly reducing anoxic depositional environments. Slightly oriented disseminated pyrite crystals and pyrhotite patches are observed within this black mudstone (see Figure 6B). The microscopic description of this ore type revealed its composition from large black sphalerite patches and domains (see Figure 6C, D). The sphalerite 


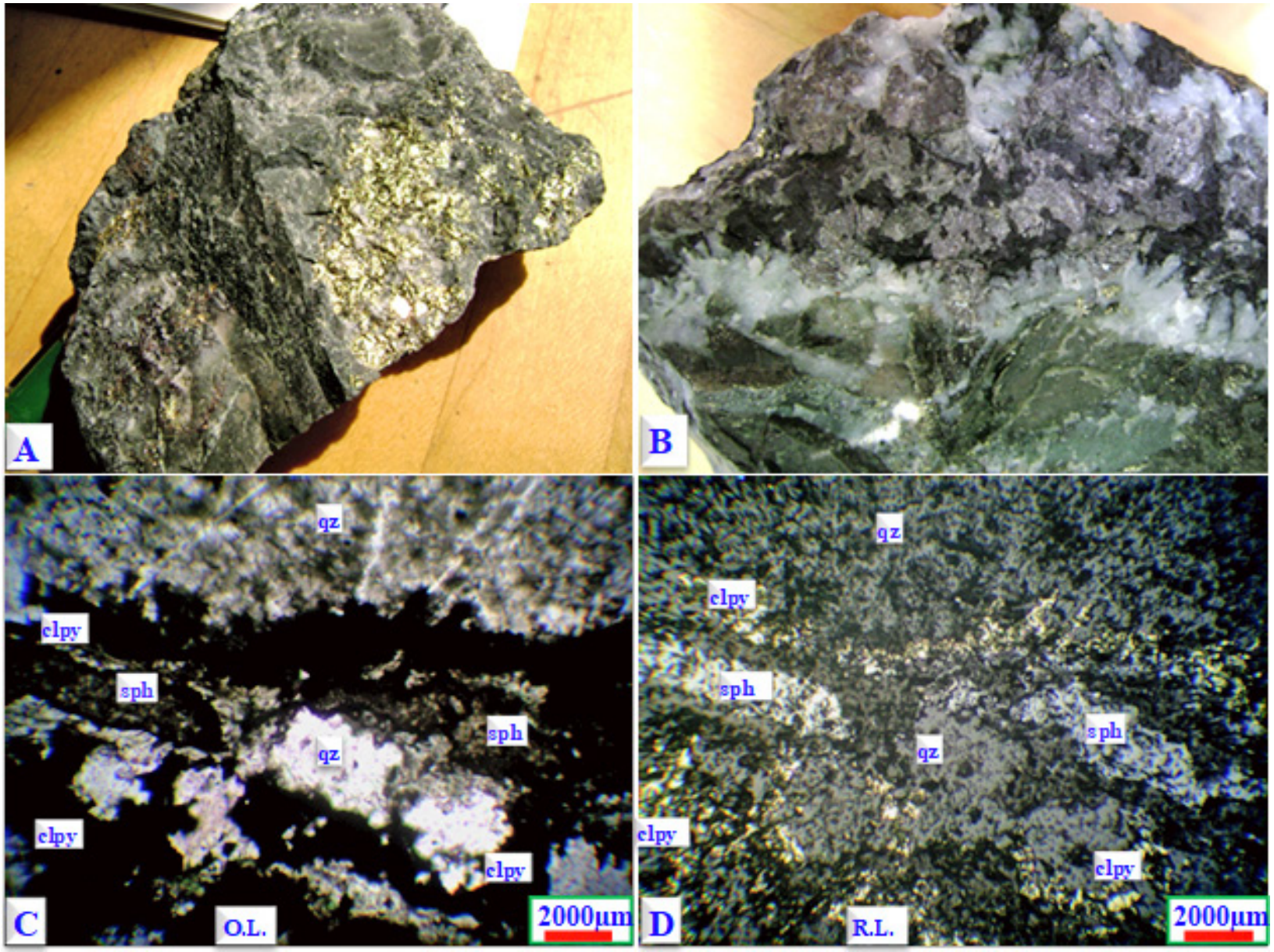

Figure 7. Sample \#5: Disseminated Sphalerite and chalcopyrite within parallel laminated greened devitrified black tuffaceous mudstone

Keynotes for Figure 7. A = Light tuffaceous mudstone contains coarse crystalline pyrite and chalcopyrite aggregates (lightly yellow in the right part of the photo); B = Parallel light (devitrified) and dark slightly devitrified band; C, D = Small sphalerite (sph) domains and chalcopyrite patches (clpy) are also observed formed instead of the greened silicified tuffaceous material.

domains are rimmed in some areas by chalcopyrite (see Figure 6E, F). It is observed here that the green chloritized patches and domains are easily replaced by sphalerite and /or chalcopyrite. Therefore, sample \#4 is called Sphalerite and chalcopyrite-bearing devitrified friable black tuffaceous mudstone.

\subsubsection{Petrographic Examination of Sample \#5}

In this ore type, light tuffaceous mudstone contains coarse crystalline pyrite and chalcopyrite aggregates (see Figure 7A). This tuffaceous black mudstone also contains some greenish black devitrified tuffaceous mudstone (see Figure 7B). The microscopic description of these samples revealed the following mineral compositions and texture: i) The original rock is composed of green chloritized silicified tuffaceous mudstone, ii) the mineralization begins by the formation of small irregular sphalerite and chalcopyrite patches and domains (see Figure 7C, D). Therefore, sample \#5 is called Disseminated Sphalerite and chalcopyrite within parallel laminated greened devitrified black tuffaceous mudstone.
Table 2 summarizes some mechanical, petrography properties and Bond work indices of the five tested gold ore types from the Mahd Ad Dahab mine. Sample \#1 indicates that the unconfined compressive strength and the elastic modulus are $312.4 \mathrm{MPa}$ and $87.3 \mathrm{GPa}$ respectively, whereas the Bond work index is $20.4 \mathrm{kwh} / \mathrm{ton}$. This is due to its composition which contains Chalcopyrite-bearing quartz stock works. Alternatively, sample \#1 is characterized by high hardness and a high cohesion bond between its matrices which reflects its high strength properties. Referring to Table 2 and scrutinizing the obtained mechanical properties of sample \#2; the compressive strength is $299.6 \mathrm{MPa}$, modulus of elasticity is $82.6 \mathrm{GPa}$ and the Bond work index is $19.9 \mathrm{kwh} / \mathrm{ton}$. This is related to the Chalcopyrite and Sphalerite-bearing chloritized and devitrified tuffaceous mudstone. The hardness and cohesion of such minerals are high which in turn affects the bond between their matrices. Therefore, sample \#2 requires more energy for grinding operations. The geological and mechanical properties of sample \#2 are close to that of sample \#1 due to mine site 
Table 2. Geomechanical, geological characteristics and Bond work index for the tested samples

\begin{tabular}{|c|c|c|c|c|}
\hline \multirow[b]{2}{*}{$\begin{array}{l}\text { Gold-bearing } \\
\text { ore Types }\end{array}$} & \multicolumn{2}{|c|}{ Mechanical Properties } & \multirow[b]{2}{*}{$\begin{array}{c}\text { Bond work } \\
\text { Index, } \\
\text { (kwh/ton) }\end{array}$} & \multirow[b]{2}{*}{ Geological Characteristics } \\
\hline & $\begin{array}{c}\text { Compressive } \\
\text { Strength, } \\
\text { (MPa) }\end{array}$ & $\begin{array}{c}\text { Elastic } \\
\text { Modulus } \\
\text { (GPa) }\end{array}$ & & \\
\hline Sample \#1 & 312.4 & 87.3 & 20.4 & Chalcopyrite-bearing quartz stock works \\
\hline Sample \#2 & 299.6 & 82.6 & 19.9 & $\begin{array}{l}\text { Chalcopyrite and sphalerite-bearing chloritized } \\
\text { and devitrified tuffaceous mudstone }\end{array}$ \\
\hline Sample \#3 & 287.3 & 77.1 & 19.3 & Sphalerite and Galena-bearing devitrified tuffs \\
\hline Sample \#4 & 276.5 & 72.3 & 18.7 & $\begin{array}{l}\text { Sphalerite and chalcopyrite-bearing devitrified black } \\
\text { tuffaceous mudstone }\end{array}$ \\
\hline Sample \#5 & 264.2 & 67.4 & 18.2 & $\begin{array}{l}\text { Disseminated Sphalerite and chalcopyrite within parallel } \\
\text { laminated greened devitrified black tuffaceous mudstone }\end{array}$ \\
\hline
\end{tabular}

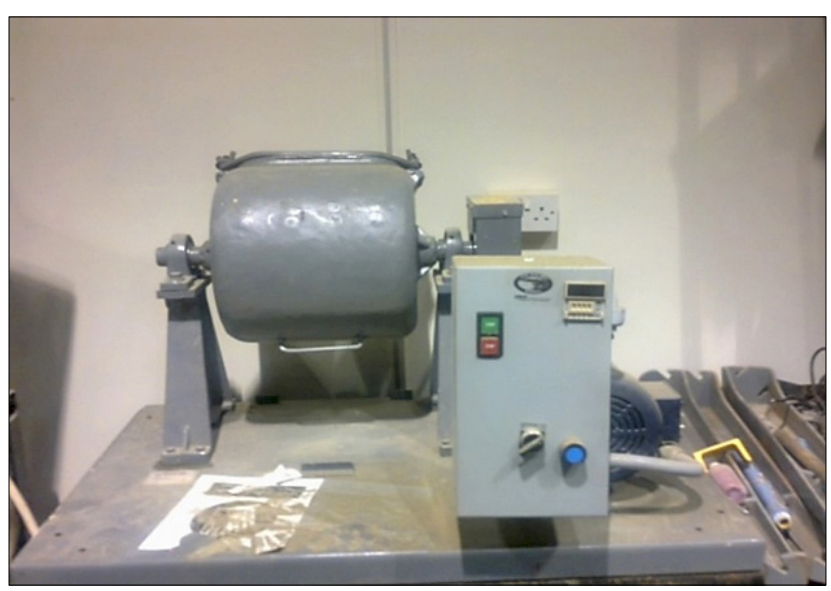

Figure 8. Lab ball mill

convergence in composition. The unconfined compressive strength and elastic modulus for sample \#3 are 287.3MPa and 77.1GPa respectively. Whereas, the Bond work index is $19.3 \mathrm{KWh} /$ ton which attributes to its mineral composition (i.e. Sphalerite and Galena-bearing devitrified tuffs). Thus, this indicates that more energy is required for grinding (i.e. due to high hardness and strong cohesion between matrices).

The magnitudes of unconfined compressive strength and elastic modulus for sample \#4 are $276.5 \mathrm{MPa}$ and $72.3 \mathrm{GPa}$ respectively. Consequently, it gives a Bond work index of $18.7 \mathrm{KWh} /$ ton due to its mineralogical composition (i.e. Sphalerite and chalcopyrite-bearing devitrified black tuffaceous mudstone) which requires less energy compared to sample \#1. The results unveiled that the unconfined compressive strength and elastic modulus of sample \#5 are 264.2MPa and 67.4GPa respectively, while its Bond work index is $18.2 \mathrm{KWh} /$ ton (i.e. due to disseminated Sphalerite and chalcopyrite within parallel laminated greened devitrified black tuffaceous mudstone). According to mineral contents and bonds between the matrices, sample \#5 is the lowest in hardness and cohesion. Therefore, less energy consumption is required for grinding operations. The details of the petrographical and mineralogical examination indi- cated that the calculated Bond work indices are slightly different for each tested sample. The maximum difference between these values is about $11 \%$. In addition, it is noticed that the approximated average interval between the two-sequenced tested samples is almost $2.5-3.0 \%$. Therefore, the effect of low variations, in the mechanical properties and petrographical characteristics, leads to a low significant effect on the energy in the grinding process.

\section{Conclusion}

This study presents the relationship between some mechanical (e.g. unconfined compressive strength and elastic modulus), petrographical properties, and the consumed power in the grinding of gold ore in the Mahd Ad Dahab mine. The described gold-bearing ore types show different mineralogical compositions and textures which are reflected in variations in their mechanical properties (i.e. unconfined compressive Strength, elastic modulus, and Bond work index).

According to this study, the following points can be concluded:

- Geological characterizing and mechanical properties (e.g. unconfined compressive strength and elastic modulus) of the gold samples are very important to evaluate the Bond work index.

- Slight correlations between the Bond work indices and the different ore types of the Mahd Ad Dahab gold mine, (KSA), were obtained. Alternatively, the estimated amount of energy consumed in grinding varies between $20.4 \mathrm{kWh} /$ ton (e.g. sample \#1) and $18.2 \mathrm{kWh} /$ ton (e.g. sample \#5).

- The variation of the mineral composition of the different ore types of the Mahd Ad Dahab gold ores has a low significant effect on the Bond work index. Whereas, a decrease in the Bond work index from ore type \#1 into ore type \#5 was revealed. This is related to the variations of the percentage of the different sulphide minerals in the different ore types and the low variation in the hardness of these min- 
erals. Pyrite and chalcopyrite are harder than sphalerite and galena, which led to less variation in the Bond work index. Also, the degree of cohesion of the ore minerals with the enclosing gangue minerals in one hand and the variation in the composition of the gangue minerals in the other hand play an important factor in the mineral processes.

- The calculated Bond work indices were slightly varied among the tested ore samples.

- The maximum difference in the Bond work index for the five Mahd Ad Dahab gold ores is about $11 \%$, and the approximated average interval between the two-sequenced types of ore tested is only $2.5-3 \%$.

- To raise the efficiency of a mineral processing plant, the impact of mineral content and its liberation size on the amount of energy consumed during grinding needs to be investigated using rocks of different strength properties (i.e. strong, medium and weak).

\section{Acknowledgments}

The author expresses his sincere gratitude to Prof. Ali A. Mesaed for his invaluable help during the evaluation of the petrographical property analyses.

\section{References}

Abdel Haffez, G.S. (2012): Correlation Between Work Index and Mechanical Properties of Some Saudi ores. Journal of Material Testing, 54, 2, 108- 112. https://doi.org/10.3139 $/ 120.110302$.

Adem, A.K. (2012): Reducing energy consumption of a raw mill in cement industry. Energy, 42, 1, 261-269. https:// doi.org/10.1016/j.energy.2012.03.060.

Afifi, A.M. (1989): Geology of the Mahd adh Dhahab district, Kingdom of Saudi Arabia: Saudi Arabian Directorate General of Mineral Resources Open-File. Report USGSOF-09-2, 49 p.

Ahmadi, R. and Shahsavari, SH. (2009): Procedure for determination of ball Bond work index in the commercial operations. Minerals Engineering, 22, 1, 104-106. https://doi. org/10.1016/j.mineng.2008.04.008.

Atilla, Ö., Nasuf, E., and Bilginm, N., (2004): The assessment of rock cutability, and physical and mechanical rock properties from a texture coefficient. The South African Institute of Mining and Metallurgy, 104, 7, 397-402. https:// www.saimm.co.za/Journal/v104n07p397.pdf

Azzoni, A., Bailo, F., and Rodena, E. (1996): Assessment of texture coefficient for different rock types and correlation with uniaxial compressive strength and rock weathering. Rock Mech. Rock Eng., 29,1, 39-46. https://doi.org/ 10.1007/BF01019938

Badr, S., and Abdel Haffez, G.S. (2014): Numerical Modeling of Macro-Scale Brittle Rock Crushing during Impacts. Materials testing. 56, 1, 70-75. https://doi.org/10.3139/ 120.110527

Barudžija, U., Maričić, A., and Brčić, V. (2015): Influence of Lithofacies and Diagenetic Processes on the Physical and
Mechanical Properties of Carbonate Rocks - Case Study from Sinawin-Sha'wa Area, Libya. Rudarsko-geološkonaftni zbornik (The Mining-Geological-Petroleum Bulletin), 30, 1, 19-36. DOI: 10.17794/rgn.2015.1.2.

Csőke, B., Rácz, Á. And Mucsi, G. (2013): Determination of the Bond work index of binary mixtures by different methods. International Journal of Mineral Processing. 123, 7886. https://doi.org/10.1016/j.minpro.2013.05.004

Deniz, A., Hakan B., Okay A. and Namık, A. (2015): Copper ore grinding in a mobile vertical roller mill pilot plant. International Journal of Mineral Processing, 136, 10, 32-36. https://doi.org/10.1016/j.minpro.2014.10.002

Deniz, V., and Onur, T. (2002): Investigation of the breakage kinetic of pumice samples as dependent on powder filling in a ball mill. Int. Journal of Mineral Processing. 67, 1-4, 71-78. https://doi.org/10.1016/S0301-7516(02)00041-8

Ersoy, A., and Waller, M.D. (1995): Textural characterisation of rocks. Engineering Geology. 39, 3-4, 123-136. https:// doi.org/10.1016/0013-7952(95)00005-Z

Hakim, H.D. (1978): Geology and genesis of gold-silver base metal sulphide-bearing veins at Mahd Ad Dhahab. University of Western Ontario, London. 204 p.

Howarth, D.F., and Rowlands, J.C. (1986): Development of an index to quantify rock texture for qualitative assessment of intact rock properties. Geotechnical Testing Journal. 9, 4, 169-179. https://doi.org/10.1520/GTJ10627J

Howarth, D.F., and Rowlands, J.C. (1987): Quantitative assessment of rock texture and correlation with drillability and strength properties. Rock Mechanics and Rock Engineering. 20, 1, 57-85. https://doi.org/10.1007/BF01019511

Ipek, H., Ucbas, Y., and Hosten., C. (2005): Ternary-mixture grinding of ceramic raw materials. Minerals Engineering. 18, 1, 45-49. https://doi.org/10.1016/j.mineng.2004.05.006

Kassem, O., Al Bassam, A., Zaidi, F.K. (2013): Structural Analysis for Metavolcanics and Their Metapyroclastics at Gold Deposit of the Mahd Ad Dahab Area, Arabian Shield, Saudi Arabia. Geology of ore Deposits, 55, 6, 482-493. Doi:10.1134/S107570151309002X. file://C:/Users/LapMDL/Downloads/GeologyoforeDeposits.pdf.

Kwaśniewski, M. (2013): Comments on the ISRM Suggested Method "A Failure Criterion for Rocks Based on True Triaxial Testing. Rock Mechanics and Rock Engineering. 46,4, 917-919. https://doi.org/10.1007/s00603-013-0407-6

Kekec, B., Unal, M., and Sensogu, C. ( 2006): Effect of the textural properties of rocks on their crushing and grinding features. Journal of University of Science and Technology Beijing, Mineral, Metallurgy, Material, 13, 5, 385-392. https://doi.org/10.1016/S1005-8850(06)60079-0

Kemp, J., Gros, Y., and Prian, J.P. (1982): Geologic map of the Mahd adh Dhahab quadrangle sheet 23E, Kingdom of Saudi Arabia: Saudi Arabian Deputy Ministry for Mineral Resources Geologic Map GM-64, scale 1:250,000. https:// discover.libraryhub.jisc.ac.uk/search?q=held-by $\% 3 \mathrm{~A} \% 20$ cam\&rn $=9$

Leiss, B, Ullemeyer, K., and. Weber, K. ( 2000): Introduction to the special issue: Textures and physical properties of rocks. Journal of Structural Geology.22, (11-12), 15271529. https://doi.org/10.1016/S0191-8141(00)00113-9 
Liang, W., Yang, C., Zhao, Y., Dusseault, M.B., and Liu, J. (2007): Experimental investigation of mechanical properties of bedded salt rock. International Journal of Rock Mechanics and Mining Sciences. 44,3, 400-411. https://doi. org/10.1016/j.ijrmms.2006.09.007

Lin, H., Cao, P., Wang, Y. (2013): Numerical simulation of a layered rock under triaxial compression. International Journal of Rock Mechanics and Mining Sciences. 60, 1218. https://doi.org/10.1016/j.ijrmms.2012.12.027

Mucsi, G., Rácz, Á., Mag, G., Antal, G. and Csőke, B. (2019): Volume based closed-cycle Hardgrove grindability method. Rudarsko-geološko-naftni zbornik (The Mining-Geological-Petroleum Bulletin), 34, 4, 9-17. Retrieved from https://hrcak.srce.hr/ojs/index.php/rgn/article/view/8851/ 5321. DOI: $10.17794 /$ rgn.2019.4.2

Ocak, I. (2008): Estimating the modulus of elasticity of the rock material from compressive strength and unit weight. Journal- South African Institute of Mining and Metallurgy. 108, 10, 621-626. http://www.scielo.org.za/pdf/jsaimm/ v108n10/06.pdf

Ozturk, A.C., and Nasuf, E. (2002): Investigation of textural properties of rocks during different loading conditions. In: ROCKMEC'2002- VIth Regional Rock Mechanics Symposium, Konya, $147 \mathrm{p}$.

Park, B., and Min, K.-B. (2015): Bonded-particle discrete element modeling of mechanical behavior of transversely isotropic rock. International Journal of Rock Mechanics and Mining Sciences. 76, 243-255. https://doi.org/10.1016/j. ijrmms.2015.03.014
Paterson, S., and Wong, T. (2005): Experimental Rock Deformation -The Brittle Field. Published by Springer-Verlag Berlin, Heidelberg, The Netherlands, 347 p.

Petrakis, E., Stamboliadis, E., and Komnitsas, K. (2017): Evaluation of the relationship between energy input and particle size distribution in comminution with the use of piecewise regression analysis. Journal of particulate Science and Technology, 35, 4, 479-489. https://doi.org/10.10 $80 / 02726351.2016 .1168894$

Rhodes, M., and Penna, F. (2009): Flowsheet development for the Sukari gold project in Egypt. In: World Gold Conference, The Southern African Institute of Mining and Metallurgy, South Africa, 279-286. http://www.saimm.co.za/ Conferences/WorldGold2009/279-286_Rhodes.pdf

Korman, T., Bedeković, G., Kujundžić, T. and Kuhinek, D. (2015): Impact of Physical and Mechanical Properties of Rocks on Energy Consumption of Jaw Crusher. Physicochemical Problems of Mineral Processing. 51, 2, 461-475. DOI: $10.5277 /$ ppmp 150208

Vyhmeister, E., Reyes-Bozob, L., Rodriguez-Maeckerc, R., Fúnez-Guerra, C., Cepeda-Vacac, F., and Valdés-González, H. (2019): Modeling and energy-based model predictive control of high pressure. Minerals Engineering, 134, 7-15. https://doi.org/10.1016/j.mineng.2019.01.016

Yuce, A.E. (2017): Grinding size estimation and beneficiation studies based on simple properties of ore components. Physicochemical Problems of Mineral Processing. 53, 1, 541-552. DOI: $10.5277 /$ ppmp 170142

\section{SAŽETAK}

\section{Izučavanje utjecaja teksture rude na vrijednost indeksa Bond Work, primjer rudnika zlata Mahd Ad Dahab}

Proces mljevenja u industrijskim kugličnim mlinovima temeljni je postupak, ujedno energijski najzahtjevniji. Stoga se velik ekonomski dobitak može ostvariti upravo, makar i malenim, napredcima u učinkovitosti toga procesa. Petrografske varijacije zlatonosne rude utječu na njezina mehanička svojstva, a time i na mljevenje. Istražene su različite vrste takve rude prikupljene u rudniku Mahd Ad Dahab. Ispitana su neka od mehaničkih i fizičkih svojstava, načinjena je geološka karakterizacija te izračunan indeks Bond Work. Indeksne vrijednosti rasle su usporedno s čvrstoćom stijena. Najveća razlika u vrijednostima indeksa za pet odabranih uzoraka bila je $11 \%$ (npr. (20,4 kWh/tona - 18.2 kWh/tona)/(20,4 kWh/ tona) $\times 100 \cong 11 \%$ ), dok je prosječni interval između dviju sekvencija testirane rude bio približno 2,5\%. (npr. 20,4 kWh/ tona $-19,9 \mathrm{kWh} /$ tona $) /(20,4 \mathrm{kWh} /$ tona $) \times 100 \cong 2,5 \%)$.

\section{Ključne riječi:}

mljevenje, indeks Bond Work, petrografija zlatne rude, rudnik Mahd Ad Dahab

\section{Author contribution}

Gamal Abdelhaffez (Associate Professor, Ph.D., mineral processing/ore dressing) collected rock samples, conducted all experimental work, interpreted the results, and wrote the entire manuscript. 